\title{
2.5 5 GROUNDNUT SCHEME IN EAST AFRICA
}

$\mathrm{R}$ EADING the first annual report and accounts for 1948-49 of the Overseas Food Corporation*, the reader gets tho impression that the high hopes with which (tast African groundnut scheme was launched fas ded rapidly. Certainly, not only the hopes but 9 so the scheme itself would have gone had not the Corporation been able to call, to the tune of $£ 23,000,000$, on the apparently bottomless purse of the British Treasury. Of this sum, about $£ 14,000,000$ is represented in the accounts by fixed and current assets, and $£ 9,000,000$ by "development, land clearing and agriculture". For the expenditure of the latter sum no return has yet been obtained. During the year $1948-49,50,000$ acres were sown to groundnuts and sunflowers, instead of the 600,000 originally planned; but the clearing of the 50,000 acres cost nearly as much as the clearing of the 600,000 acres was expected to cost. Incredible miscalculations were made, and experience was bought at heavy cost to the taxpayer. Nevertheless, a beginning has been made which, had the scheme been laid down on a more moderate scale and carried out less extravagantly, would have been considered a good one. The report strengthens the opinion held in many quarters that the correct procedure would have been to gain experience on a 'pilot-plant' scale before launching out on to the perilous and uncharted seas of large-scale production. The work of the Scientific Department, established in January 1947, would probably also have benefited by being concentrated on a pilot plant instead of covering the whole field of actual operations, although it is clearly too early to assess research results after only two years.

The report of the Scientific Department occupies about a third of the whole annual report, and deals with the period from its inception in January 1947 to the end of the 1947-48 crop season. The first duty of the chief scientific officer (Dr. A. H. Bunting) was defined as the carrying out of research and the collection of scientific data to form the basis of the agricultural and soil-conserving measures to be used. "The first object is the institution of agricultural methods capable of giving maximum yields consistent with the maintenance of soil fertility. Investigation of the production of other food crops will have to be pursued concurrently, both to feed the personnel and as a basis for the future developments outlined in the [Wakefield] Mission's report, should these be undertaken." At present, matters involving animal hus. bandry are excluded from the Department's purview, though as the inclusion of animal husbandry in the agricultural system becomes possible it is expected that problems of mixed farming will be studied.

During the period under review, the Department's staff consisted of the chief scientific officer, a chemist, three soil surveyors, an analyst, an agronomist, a statistician and an entomologist. Work done consisted principally of rapid reconnaissance surveys of areas proposed for development, soil-fertility and fertilizer studies based on the surveys, experimental work on groundnuts and other crops, preliminary

* Overseas Food Corporation. First Annual Report and Statement of Accounts for the Period ended March 31, 1949. Pp. vi +158 (London: H.M. Stationery Office, 1949.) 3s. $6 d$. net. surveys of insect and disease attacks on groundnuts, etc., and laboratory work on soils and the determ. ination of the oil content of oil seeds.

The surveys were of necessity exploratory. The soils, however, were described in general terms, but with sufficient detail to distinguish the major types, and test crops were grown on some soils to get an idea of their productivity.

Numerous soil analyses have shown that all the soils at the main centre of operations at Kongwa are poor in phosphates and nitrogen, but rich in potash. It was expected, therefore, that groundnuts would respond to phosphate but not to potash, and the first fertilizer experiments have confirmed this. A small positive response was obtained to nitrogen alone, but a negative response when nitrogen was applied with phosphate. Responses to both nitrogen and phosphate were enhanced by placing the fertilizer in bands to the side of the seed instead of broadcasting, but the conclusion drawn is that probably only phosphate will give an economic return at Kongwa. Other crops, such as sunflower, likely to be grown will probably require nitrogen also.

Soil conservation is said not to be the duty of the Scientific Department; nevertheless in so far as the Department is concerned with the development of a scientifically based, stable system of agriculture, it will encounter problems of soil conservation at every turn. Soil erosion has not yet become a serious problem, and at Kongwa it was effectively controlled by laying out level contours in the cleared ground and piling the cleared debris in windrows on the contours. This is a temporary measure which it is expected will be superseded by a system of broadbased contour terraces.

Experiments were initiated to determine the effects on groundnut yield of such factors as plant variety, plant population, time of planting, and methods of cultivation and harvesting. Although the results for one season will require confirmation, definite indications were obtained that early planting is necessary to obtain the highest yields. The oil contents of different varieties tend to vary inversely with the yields, so that the yield of oil per acre does not vary much from one variety to another. Varieties with an upright growth have the lowest yield of kernels with the highest oil content.

In the original White Paper on the scheme, a rotation of two years of groundnuts followed by two years of grass ley to restore soil fertility was sug. gested. It appears to be unlikely that this suggestion will be adopted immediately, mainly because ley farming, to be economic, involves the building-up of livestock herds to utilize the ley, and of water supplies. In 1948 sunflowers were the only crop other than groundnuts to be grown on a large scule, and, indeed, were sown on an almost equal acreage. They appear to be a promising alternative oil orop, in some respects more reliable than groundnuts. For future planning, a rotation of groundnut, sunflower and a grass resting-crop was assumed at the time the report was written. Tests with many other crops were made by the Scientific Department, the ultimate objective being to develop systems of farming suited to the varying conditions in which the Corporation is interested. 
Work on plant protection was confined chiefly to entomological investigations, the most serious threat to groundnut production coming from the presence of Hilda patruelis. It is expected that the virus causing rosette will cause trouble in the near future ; but in the 1948 season diseases do not seem to have been serious.

Investigations on the quality of the groundnut oils produced at Kongwa by Prof. T. P. Hilditch, of the University of Liverpool, showed that they were of very high quality, and in colour and free acidity they "far surpass any raw groundnut oil which has hitherto been on the English market". The oils had an excep. tionally high iodine value, but were liable to deteriorate in presence of moisture.

An Operational Research Unit was established in 1949 to carry out research on land-clearing, agricultural, civil-engineering and transport problems, as it had been found that tests made in England on plant and equipment had little value for East African conditions. The Unit has had considerable success in developing a chain-cable clearing of bush. A heavy. 3 -inch chain cable is attached to two heavy tractors which move through the bush 20-30 ft. apart, and a third tractor follows to deal with particularly stout trees which the chain cable cannot pull out of the ground. The successful application of this method of flattening is cited as the outstanding achievement of the year, and promises to effect great economies in the cost of clearing, although at Kongwa it has considerably increased the wastage of tractors.

\section{G. V. JACKS}

\section{INFLUENCE OF ORGANIC NITROGEN COMPOUNDS ON NITRIFICATIONS IN SOIL}

\author{
By Prof. J. H. QUASTEL, F.R.S. \\ AND \\ DR. P. G. SCHOLEFIELD
}

\section{Montreal General Hospital Research Institute, Montreal}

$\mathrm{T}$ HE following report is intended to summarize briefly some of the main findings discovered in an investigation of the metabolism of organic nitrogen compounds in soil, with particular reference to the breakdown of amino-acids and certain allied substances. They throw light on the problem of the interference of organic matter with soil nitrification and on the chemical nature of a number of molecules that appear specifically to affect ammonia metabolism. They also point to the presence in soil of a class of organisms that can convert certain organic nitrogen compounds directly into nitrites. This report must be regarded as a preliminary statement ; full details of the experimental techniques and results (together with many that cannot adequately be mentioned here) will be given in later publications.

The method of investigation is that of continuous perfusion of a solution of the substance under investigation through a column of $30 \mathrm{gm}$. air-dried crumbed soil, under conditions where optimal aeration together ith water saturation, but no waterlogging, occurs. method of soil perfusion has already been acribed by Lees and Quastel ${ }^{1}$ in their studies ion in soil; but the apparatus now used is Audus's modification ${ }^{2}$ of the original one used by the above workers. Among the various conclusions reached by Lees and Quastel the following bear upon the subject of the present inquiry.

(1) When nitrification takes place in a soil, the nitrifying organisms develop largely on the surfaces of the soil crumbs. During the initial perfusion of an air-dried soil this process may be of long duration, since the logarithmic growth phase is involved; but eventually a condition arises when the sites of proliferation on the soil are saturated with the nitrifying organisms. The soil is then termed a saturated or enriched soil. Such a soil brings about a relatively rapid rate of nitrification, and this rate remains constant during subsequent perfusion of the soil with ammonium chloride. The soil, in fact, behaves like an enzyme system, no proliferation of the relevant organisms taking place except presumably to replace the dead cells.

(2) A saturated soil that nitrifies an ammonium salt at a constant rate and shows no initial lag period will not nitrify organic nitrogen compounds such as methylamine, trimethylamine and glycine at constant rates. A lag period occurs, showing that organisms must first develop that can convert these compounds into free ammonia which is afterwards nitrified. On the other hand, it was found that nitrification of pyruvic oxime shows little or no lag, and it seemed possible that this molecule may play a significant part in the process of nitrification.

\section{Nitrification of Ammonium Chloride and Glycine}

If the conversion of glycine into nitrate by soil bacteria always requires the intermediate production of the ammonium ion, it follows that the rate of nitrification of glycine should never exceed that of ammonium chloride, under identical experimental conditions and for equal quantities of nitrogen. Experiment, however, shows that this is not always the case. A few typical results are shown in Table 1.

Table 1

\begin{tabular}{|c|c|c|c|c|c|}
\hline \multirow{3}{*}{$\begin{array}{l}\text { Garden } \\
\text { soils }\end{array}$} & \multirow{3}{*}{$p \mathrm{H}$} & \multicolumn{4}{|c|}{$\begin{array}{l}\mu \mathrm{gm} \text {. } \mathrm{NO}^{\prime}-\mathrm{Nitrogen} / \mathrm{ml} \text {. formed on con- } \\
\text { tinuous perfusion at } 70^{\circ} \mathrm{F} \text {. Maximum } \\
\text { possible }=140 \mu \mathrm{gm} . / \mathrm{ml} \text {. }\end{array}$} \\
\hline & & \multicolumn{2}{|c|}{$\begin{array}{c}\text { Ammonium chloride } \\
(0.01 M)\end{array}$} & \multicolumn{2}{|c|}{$\begin{array}{r}\text { Glycine } \\
(0.01 M)\end{array}$} \\
\hline & & $\begin{array}{l}\text { First } \\
\text { perfusion } \\
\text { (15 days) }\end{array}$ & $\begin{array}{l}\text { Second } \\
\text { perfusion } \\
\text { (13 days) }\end{array}$ & $\begin{array}{l}\text { First } \\
\text { perfusion } \\
\text { (15 days) }\end{array}$ & $\begin{array}{l}\text { Second } \\
\text { perfusion } \\
\text { (13 days) }\end{array}$ \\
\hline III & $\begin{array}{l}4 \cdot 5 \\
6 \cdot 5 \\
7 \cdot 6\end{array}$ & $\begin{array}{r}10 \\
82 \\
113\end{array}$ & $\overline{18}$ & $\begin{array}{r}10 \\
134 \\
140\end{array}$ & $\overrightarrow{98}$ \\
\hline
\end{tabular}

Here it will be seen that with a soil of $p H 6.5$ the rate of nitrification of glycine exceeds that of ammonium chloride and that such a soil on perfusion with glycine may become enriched with nitrifying organisms while the same soil perfused with an equimolar solution of ammonium chloride fails to show such an enrichment. A neutral or slightly alkaline soil, on the other hand, favours the nitrification of ammonium chloride rather than that of glycine, while a distinctly acid soil $(p H \mathbf{H} \cdot 5)$ fails to nitrify either molecule satisfactorily. The phenomenon whereby a slightly acid soil (and many agricultural soils are of this nature) brings about a preferential nitrification of an organic nitrogen compound such as glycine must, of course, be of 